PROPERTIES OF CAST MAR-M-247 FOR TURBINE BLISK APPLICATIONS

\author{
Murray Kaufman \\ Thomson Laboratory \\ Cencral Electric Company \\ Lynn, Massachusetts 01910 \\ USA
}

Summary

The following mechanical properties of specimens cut from turbine blade/ disk (blisk) castings of Mar-M-247 alloy are presented: tensile (smooth and notched), crecp/rupture, high cycle fatigue, low cycle fatigue and crack growth rate. Results of an extensive search for the presence of defects in the blisk castings are reported 
Production of a turbine blade/disk rotor (blisk) as a one piece casting would offer a significant cost reduction compared to the conventional cast blade-dovetail-wrought disk rotor, as well as avoiding certain stress problems caused by the dovetail type of blade attachment. In the past, alloy and casting technology could not produce dimensionally accurate, sound castings, of adequate mechanical properties, particularly for the disk portion of the casting for application in high performance turbines in competition with conventional rotors. Cast nickel base superalloys have long established usage as turbine blades, but their disk area temperature tensile and fatigue properties are considerably lower than the better forged disk alloys, in part due to the much coarser grain size of the castings in the thicker sections of a disk. A recent improvement in casting technology is the Grainex $(R)$ process of Hownet Turbine Components Corp. (I) for producing fine grains in thick sections. Combined with the capability of Hot Isostatic Pressing (HIP) to close internal porosities, it seems possible now to use castings in high performance blisk applications.

of the various potential alloys for cast blisks, Mar-M-247 appears to have good castability, adequate strength levels and there is some structural information available $(1-5)$. The purpose of the present work is to provide some basic mechanical properties, including smooth and notch tensile, creep-rupture, low and high cycle fatigue and crack growth rate on specimens cut from actual blisks, Grainex $(R)$ cast and HIP'd with the parameters established for production. In addition, because modern design methods use defect tolerance analysis, it is essential to obtain some measure of the distribution of defects, such as non-metallic inclusions and remaining porosity in actual castings. Both inspection of metallographic sections and test bar fracture surfaces are included.

\section{Materials and Test Conditions}

Al1 material for testing in this program was obtained from a group of 14 Mar-M-247 blisks cast by the Grainex (R) process, HIP'd at $2165 \mathrm{~F}, 25 \mathrm{Ksi}$ for 4 hours and heat treated at 2165F, 2 hours, plus 1600F, 20 hours by Howmet Turbine Components Corp., Austenal LaPorte Division. Five different cast configurations were involved, all with disk diameters of about 6", solid centers with hub thicknesses of about $2 \frac{1}{2}$ " and web thicknesses of 0.6 to $0.75^{\prime \prime}$. Four master heats were represented (at least 2 blisks from each heat), 2 different HIP runs, and several different heat treat lots. Table I shows the chemical compositions of each of the 4 heats involved. Note that 4 different master melt sources are involved. Compositions are within the requirements for the alloy.

Specimens were cut from the blisks in the radial and tangential orientation (no axial bars). Smooth tensile and creep rupture bars had $1 / 2$ " dia. $\mathrm{x}{ }^{\prime \prime}$ long gage sections. Notched tensile bars had $\frac{1}{2} "$ minfmum dia. with a $\mathrm{K}_{\mathrm{t}}=2.8$ notch. Fatigue test bars used a cylindrical gage section, 0.2 " dia.; $3 / 4$ " long for LCF and $\frac{1}{2} "$ long for HCF testing. Crack growth specimens were of the compact tensile type, $\frac{1 / 2}{2}$ thick and $\sim 1.85 "$ square.

Tensile tests were run at R.T., 400, 1000, 1200, 1400, 1600, 1800 and $1900 \mathrm{~F}$ for smooth bars and R.T., 1000 and $1400 \mathrm{~F}$ for notched bars ( 2 or 3 at each temperature). Creep rupture tests were run at 1400,1600 and $1800 \mathrm{~F}$ ( 3 or 4 per temperature). Crack growth tests were performed at $A=0.95$, in duplicate, at 1000 and 1400F. Both low cycle fatigue (LCF) and high 
Table I. Composition of Mar-M-247 Heats

(Weight \%)

\begin{tabular}{|c|c|c|c|c|}
\hline Element & $\begin{array}{c}\text { L11-WWS } \\
\text { Cert. Alloy } \\
\text { Prod. }\end{array}$ & $\begin{array}{l}\text { L11-WLK } \\
\text { Cannon- } \\
\text { Muskegon }\end{array}$ & $\begin{array}{l}\text { L11-WLB } \\
\text { Special } \\
\text { Metals }\end{array}$ & $\begin{array}{l}\text { L11-WST } \\
\text { Howmet } \\
\text { Dover }\end{array}$ \\
\hline $\begin{array}{l}\mathrm{Al} \\
\mathrm{Ti} \\
\mathrm{Co} \\
\mathrm{Cr} \\
\mathrm{Mo} \\
\mathrm{W} \\
\mathrm{Ta} \\
\mathrm{Hf} \\
\mathrm{Fe} \\
\mathrm{C} \\
\mathrm{B} \\
\mathrm{Zr} \\
\mathrm{Si} \\
\mathrm{Mn} \\
\mathrm{S} \\
\mathrm{N} \\
0 \\
\mathrm{Ni}\end{array}$ & $\begin{array}{c}5.57 \\
1.09 \\
10.05 \\
8.51 \\
.71 \\
9.87 \\
2.99 \\
1.55 \\
.16 \\
.14 \\
.016 \\
.03 \\
<.1 \\
<.1 \\
.0002 \\
10 \mathrm{ppm} \\
18 \mathrm{ppm} \\
\mathrm{Ba} 1 .\end{array}$ & $\begin{array}{c}5.50 \\
1.00 \\
10.15 \\
8.63 \\
.73 \\
9.67 \\
3.00 \\
1.40 \\
.04 \\
.17 \\
.013 \\
.04 \\
<.05 \\
<.05 \\
.0004 \\
6 \mathrm{ppm} \\
14 \mathrm{ppm} \\
\mathrm{Ba1} .\end{array}$ & $\begin{array}{c}5.55 \\
.95 \\
10.10 \\
8.51 \\
.77 \\
9.65 \\
2.91 \\
1.47 \\
.04 \\
.17 \\
.015 \\
.04 \\
<.05 \\
<.05 \\
.0004 \\
3 \mathrm{ppm} \\
10 \mathrm{ppm} \\
\mathrm{Ba1}\end{array}$ & $\begin{array}{c}5.42 \\
1.03 \\
10.00 \\
8.40 \\
.78 \\
10.00 \\
2.90 \\
1.41 \\
.08 \\
.13 \\
.015 \\
.03 \\
<.05 \\
<.05 \\
.0005 \\
6 \mathrm{ppm} \\
10 \mathrm{ppm} \\
\mathrm{Ba1} .\end{array}$ \\
\hline
\end{tabular}

cycle fatigue (HCF) testing was performed, LCF, axial-axial, strain control, at $A=1$ was run at 400,1000 and $1400 \mathrm{~F}, 8$ specimens each. HCF testing, axial-axial at $A=\infty, 0.67$ and 0.25 was done at 1100 and $1700 \mathrm{~F}$ and $\mathrm{At}=\infty$ and 0.25 at $1500 \mathrm{~F}, 4$ to 6 specimens at each condition.

Metallographic inspection of many test bars and sections cut from the blisks was performed to examine both the microstructure and for presence of defects. All the fracture surfaces of the failed fatigue bars and some of the others were examined optically and by SEM. Any "defects" found were analyzed by X-ray energy dispersive (EDX) techniques.

\section{Test Results}

The tensile data is included in Table II. In these, and other tests, no significant differences appeared as a function of specimen orientation or blisk source; only the Heat number is reported here. Both $0.2 \%$ yield strength and ultimate tensile strength remain about constant up to $1400 \mathrm{~F}$, above which they decrease moderately rapidly. The ductility shows a slight rise up to 1000F, followed by the usual nickel base alloy ductility minimum near $1600 \mathrm{~F}$. Notched bar tensile strength is always greater than the smooth bar strength, with the notch/smooth ratios as follows:

$\begin{array}{cc}\text { Temperature } & \text { Notch/Smooth UTS Ratio } \\ \text { R.T. } & 1.33 \\ 1000 \mathrm{~F} & 1.27 \\ \text { 1400F } & 1.14\end{array}$


Table IT. Mar-M-247 Tensile Test Results

\begin{tabular}{|c|c|c|c|c|c|c|}
\hline $\begin{array}{l}\text { Test } \\
\text { Temp. } \\
\text { OF }_{F}\end{array}$ & $\begin{array}{l}\text { Test } \\
\text { Type }\end{array}$ & $\begin{array}{l}\text { Spec. } \\
\text { Heat }\end{array}$ & $\begin{array}{c}0.2 \% \text { YS } \\
\text { ksi }\end{array}$ & $\begin{array}{c}\text { U.T.S. } \\
\text { ksi }\end{array}$ & $\underset{\%}{\text { Elong. }}$ & R. of $\mathrm{A}$. \\
\hline \multirow[t]{2}{*}{ R.T. } & Smooth & $\begin{array}{l}\text { WWS } \\
\text { WLK } \\
\text { WLB B }\end{array}$ & $\begin{array}{l}124.7 \\
120.8 \\
126.1\end{array}$ & $\begin{array}{l}143.4 \\
142.9 \\
142.5\end{array}$ & $\begin{array}{l}5.9 \\
7.3 \\
6.5\end{array}$ & $\begin{array}{l}7.1 \\
8.2 \\
9.4\end{array}$ \\
\hline & $k_{t}=2.8$ & $\begin{array}{l}\text { WWS } \\
\text { WLKK } \\
\text { WST }\end{array}$ & $\begin{array}{l}- \\
\overline{-}\end{array}$ & $\begin{array}{l}188.2 \\
196.1 \\
186.3\end{array}$ & $\begin{array}{l}- \\
-\end{array}$ & $\begin{array}{l}- \\
-\end{array}$ \\
\hline 400 & Smooth & $\begin{array}{l}\text { WWS } \\
\text { WL.K }\end{array}$ & $\begin{array}{l}117.6 \\
117.9\end{array}$ & $\begin{array}{l}143.3 \\
148.4\end{array}$ & $\begin{array}{l}6.5 \\
7.4\end{array}$ & $\begin{array}{l}7.3 \\
8.5\end{array}$ \\
\hline \multirow[t]{2}{*}{1000} & Smooth & $\begin{array}{l}\text { WWS } \\
\text { WLK } \\
\text { WLB }\end{array}$ & $\begin{array}{l}117.7 \\
121.3 \\
116.6 \\
\end{array}$ & $\begin{array}{l}146.0 \\
152.0 \\
143.5\end{array}$ & $\begin{array}{l}7.9 \\
8.1 \\
6.6\end{array}$ & $\begin{array}{r}10.9 \\
10.4 \\
9.3\end{array}$ \\
\hline & $\mathrm{K}_{\mathrm{t}}=2.8$ & $\begin{array}{l}\text { WST } \\
\text { WLB } \\
\text { WLB }\end{array}$ & $\begin{array}{l}- \\
-\end{array}$ & $\begin{array}{l}188.6 \\
183.9 \\
189.7\end{array}$ & $\begin{array}{l}- \\
-\end{array}$ & $\begin{array}{l}- \\
-\end{array}$ \\
\hline 1200 & Smooth & $\begin{array}{l}\text { WWS } \\
\text { WWS }\end{array}$ & $\begin{array}{l}113.6 \\
118.2\end{array}$ & $\begin{array}{l}142.6 \\
150.8\end{array}$ & $\begin{array}{l}6.9 \\
7.2\end{array}$ & $\begin{array}{r}8.9 \\
10.5\end{array}$ \\
\hline \multirow[t]{2}{*}{1400} & Smooth & $\begin{array}{l}\text { WWS } \\
\text { WST }\end{array}$ & $\begin{array}{l}117.2 \\
115.3 \\
\end{array}$ & $\begin{array}{l}145.1 \\
149.0 \\
\end{array}$ & $\begin{array}{l}4.3 \\
6.1 \\
\end{array}$ & $\begin{array}{l}7.4 \\
8.2 \\
\end{array}$ \\
\hline & $\mathrm{K}_{\mathrm{t}}=2.8$ & $\begin{array}{l}\text { WST } \\
\text { WWS }\end{array}$ & $\overline{-}$ & $\begin{array}{l}161.0 \\
172.9\end{array}$ & - & $\overline{-}$ \\
\hline 1600 & Smooth & $\begin{array}{l}\text { WLK } \\
\text { WWS }\end{array}$ & $\begin{array}{l}102.2 \\
103.6\end{array}$ & $\begin{array}{l}123.7 \\
127.1\end{array}$ & $\begin{array}{l}3.2 \\
6.6\end{array}$ & $\begin{array}{l}4.6 \\
6.9 \\
\end{array}$ \\
\hline 1800 & Smooth & $\begin{array}{l}\text { WST } \\
\text { WL.K }\end{array}$ & $\begin{array}{l}61.2 \\
56.4\end{array}$ & $\begin{array}{l}82.7 \\
77.5\end{array}$ & $\begin{array}{l}6.4 \\
6.8\end{array}$ & $\begin{array}{l}8.6 \\
7.0\end{array}$ \\
\hline 1900 & Smooth & $\begin{array}{l}\text { WLK } \\
\text { WST }\end{array}$ & $\begin{array}{l}43.2 \\
38.6\end{array}$ & $\begin{array}{l}59.1 \\
55.4\end{array}$ & $\begin{array}{l}8.3 \\
9.2\end{array}$ & $\begin{array}{r}9.8 \\
10.4\end{array}$ \\
\hline
\end{tabular}

The creep rupture data is listed in Table III. The low ductility at $1400 \mathrm{~F}$ precluded the possibility obtaining 1 and $2 \%$ creep times. The creep time at $1400 \mathrm{~F}$ for the specimen from Heat WWS is higher and the elongation is lower than they should be, because of the failure outside the gage length. Al1 the other data points seem reasonable and consistent.

Table IV contains the strain controlled LCF, $A=1$, data for 400,800 and 1400F. All discernible fracture initiation sites were at the surface, except for the four lowest strain range failures at 1400F (see next section). Scatter was not very great. At the high strain region, life decreases with increasing temperature, while at low strain ranges there is no difference in the 400 and $800 \mathrm{~F}$ results, with the $1400 \mathrm{~F}$ results slightly lower.

The high cycle fatigue results for the different temperatures and $A$ ratios are summarized in Table V. All the 1100F failures seemed to be surface 
Table III. Mar-M-247 Creep Rupture Test Resu1ts

\begin{tabular}{|c|c|c|c|c|c|c|c|c|}
\hline $\begin{array}{l}\text { Test } \\
\text { Temp. } \\
\text { of }_{F}\end{array}$ & $\begin{array}{c}\text { Test } \\
\text { Stress } \\
\text { Ksi }\end{array}$ & $\begin{array}{l}\text { Heat } \\
\text { No. }\end{array}$ & $\frac{\text { Cree }}{0.5 \%}$ & $\frac{\text { Time, }}{1 \%}$ & $\frac{\mathrm{hrs} .}{2 \%}$ & $\begin{array}{l}\text { Rupture } \\
\text { Life } \\
\text { hrs. }\end{array}$ & $\underset{\%}{\text { Elong. }}$ & $\underset{\%}{\mathrm{R} . \mathrm{A}}$ \\
\hline 1400 & $\begin{array}{l}90 \\
" 1 \\
" 1\end{array}$ & $\begin{array}{l}\text { WWS* } \\
\text { WST } \\
\text { WLB }\end{array}$ & $\begin{array}{l}250 \\
125 \\
183\end{array}$ & $\begin{array}{l}- \\
-\end{array}$ & - & $\begin{array}{l}274.7 \\
140.9 \\
300.2\end{array}$ & $\begin{array}{l}1.1 \\
1.0 \\
1.5\end{array}$ & $\begin{array}{l}1.1 \\
1.9 \\
3.4\end{array}$ \\
\hline 1600 & $\begin{array}{l}55 \\
45 \\
" 1\end{array}$ & $\begin{array}{l}\text { WWS } \\
\text { WLK } \\
\text { WWS }\end{array}$ & $\begin{array}{r}42 \\
309 \\
203\end{array}$ & $\begin{array}{r}77 \\
451 \\
336\end{array}$ & $\begin{array}{c}124 \\
628 \\
-\end{array}$ & $\begin{array}{l}217.9 \\
818 \\
724.6\end{array}$ & $\begin{array}{l}7.6 \\
5.9 \\
6.1\end{array}$ & $\begin{array}{l}8.1 \\
7.5 \\
7.8\end{array}$ \\
\hline 1800 & $\begin{array}{l}25 \\
22 \\
" ~\end{array}$ & $\begin{array}{l}\text { WLB } \\
\text { WLK } \\
\text { WWS }\end{array}$ & $\begin{array}{r}57 \\
224 \\
139\end{array}$ & $\begin{array}{r}88 \\
287 \\
178\end{array}$ & $\begin{array}{l}114 \\
348 \\
214\end{array}$ & $\begin{array}{l}126.6 \\
412.1 \\
220.8\end{array}$ & $\begin{array}{l}5.4 \\
5.9 \\
4.0\end{array}$ & $\begin{array}{l}5.3 \\
8.9 \\
5.3\end{array}$ \\
\hline
\end{tabular}

*Failed outside gage length

Table IV. Mar-M-247 Low Cycle, Strain Controlled, A=1, Fatigue Test Results

\begin{tabular}{|c|c|c|c|c|c|}
\hline $\begin{array}{l}\text { Test } \\
\text { Temp. } \\
\mathrm{o}_{\mathrm{F}}\end{array}$ & $\begin{array}{r}\text { Heat } \\
\text { No. }\end{array}$ & $\begin{array}{r}\text { Strain } \\
\text { Range \% }\end{array}$ & $\begin{array}{c}\text { Mod, of Elast. } \\
10^{6} \mathrm{psi}\end{array}$ & $\begin{array}{l}\text { Cycles to } \\
\text { Initiate }\end{array}$ & $\begin{array}{l}\text { Cycles to } \\
\text { Failure }\end{array}$ \\
\hline 400 & $\begin{array}{l}\text { WWS } \\
\text { WLB } \\
\text { WWS } \\
\text { WWS } \\
\text { WST } \\
\text { WLB } \\
\text { WWS } \\
\text { WLB }\end{array}$ & $\begin{array}{l}.958 \\
.800 \\
.666 \\
.628 \\
.509 \\
.491 \\
.469 \\
.380\end{array}$ & $\begin{array}{l}30.9 \\
31.2 \\
29.9 \\
30.9 \\
30.7 \\
29.6 \\
29.9 \\
29.9\end{array}$ & $\begin{array}{r}\sim 1,070 \\
\sim 2,100 \\
- \\
\sim 9,070 \\
13,991 \\
\sim 24,000 \\
\sim 138, \overline{700}\end{array}$ & $\begin{array}{r}1,267 \\
2,646 \\
5,312 \\
9,644 \\
16,851 \\
25,861 \\
57,169 \\
145,155\end{array}$ \\
\hline 800 & $\begin{array}{l}\text { WLB } \\
\text { WLK } \\
\text { WST } \\
\text { WST } \\
\text { WLB } \\
\text { WLB } \\
\text { WWS } \\
\text { WWS }\end{array}$ & $\begin{array}{l}.994 \\
.970 \\
.834 \\
.737 \\
.694 \\
.546 \\
.488 \\
.404\end{array}$ & $\begin{array}{l}29.3 \\
28.9 \\
29.7 \\
29.8 \\
28.8 \\
29.9 \\
29.0 \\
29.6\end{array}$ & $\begin{array}{r}-\overline{630} \\
1,084 \\
2,368 \\
5,776 \\
17,600 \\
\sim 30,000 \\
\sim 73,460\end{array}$ & $\begin{array}{r}369 \\
950 \\
1,604 \\
2,845 \\
6,976 \\
20,400 \\
39,790 \\
76,429\end{array}$ \\
\hline 1400 & $\begin{array}{l}\text { WLB } \\
\text { WLK } \\
\text { WLK } \\
\text { WWS } \\
\text { WST } \\
\text { WLK } \\
\text { WST } \\
\text { WLK }\end{array}$ & $\begin{array}{l}.831 \\
.724 \\
.626 \\
.578 \\
.442 \\
.388 \\
.369 \\
.332\end{array}$ & $\begin{array}{l}25.6 \\
24.1 \\
25.2 \\
23.6 \\
25.8 \\
26.1 \\
25.7 \\
26.6\end{array}$ & $\begin{array}{r}190 \\
\sim 670 \\
2,487 \\
5,358 \\
13,764 \\
\sim 31,800 \\
-- \\
\sim 98,200\end{array}$ & $\begin{array}{r}496 \\
799 \\
3,311 \\
6,358 \\
26,244 \\
33,881 \\
179,224 \\
99,152 \\
\end{array}$ \\
\hline
\end{tabular}

Test stopped, no failure 
Table V. Mar-M-247 High Cycle Fatigue Test Summary

\begin{tabular}{|c|c|c|}
\hline $\begin{array}{c}\text { Test Temp. } \\
\text { OF }\end{array}$ & $\begin{array}{c}\text { A } \\
\text { Ratio }\end{array}$ & $\begin{array}{c}\text { Alternating } \\
\text { Fatigue Strength } \\
\text { a 10 } 7 \text { Cycles } \\
\text { ksi }\end{array}$ \\
\hline \multirow{2}{*}{1100} & $\infty$ & 32.5 \\
& .67 & 29.2 \\
& .25 & 22.1 \\
\hline \multirow{2}{*}{1500} & $\infty$ & 45.0 \\
& .25 & 18.8 \\
\hline \multirow{2}{*}{1700} & $\infty$ & 36.6 \\
& .67 & 25.0 \\
& .25 & 13.7 \\
\hline
\end{tabular}

initiated, Most of the 1500 and $1700 \mathrm{~F}$ fallures initiated internally, although the $A=\infty$ fracture surfaces were generally beaten too badly to locate the initiation sites (see next section). For $A=\infty$, there seems to be a maximum of. $10^{7}$ cycle fatigue strength at 1500F, with the $1700 \mathrm{~F}$ value somewhat higher than the 1100F. At $A=0,67$ and 0.25 , there is a continual decrease with increasing temperature.

Crack growth rate test results at 1000 and $1400 \mathrm{p}$ show: threshold stress intensfty factor $K *=8 \mathrm{Ksi} \sqrt{\mathrm{In}}$ at $1000 \mathrm{~F}$ and about 13 at 1400F. Up to a crack growth rate (dA/dN) of $10^{-4}\left(\mathbb{K}^{2}=50\right)$, the critical stress intensity factor $K_{c}$ was not reached at efther temperature. At each temperature the duplicate specimens were in good agreement, with a moderate test scatter.

Metallographic and Fractographic Examination

The microstructure of the different b1isks, and at various locations within the hub, web and $\mathrm{rim}$ regions of each blisk were relatively uniform, Maximum grain size was about 1/8". Typical structures are included in Fig, 1-3. Most noticeable, particularly in the unetched condition are the fairly common occurrence of large, elongated MC type carbides up to 10 mils long, FIg, 1. Smaller MC carbides, and occasional script-like carbides are present also. Etching reveals the usual structures for high $\mathbf{r}^{\prime}$ percentage alloys: eutectic nodules, coring and a fair amount of coarser $Y^{\prime}$, Figs. 2, 3. The long time at high temperature during HIP and heat treatment, without a $r^{\prime}$ solution treatment undoubtedly caused the coarse $r^{\prime}$.

of great interest for application as blisks, is the presence and morphology of possible defects. A total of 44 samples were mounted and polished, representing cross sections of test bars, radial and tangential slices from the blisks, etc., from each of the heats supplied. The results are summarized below: 

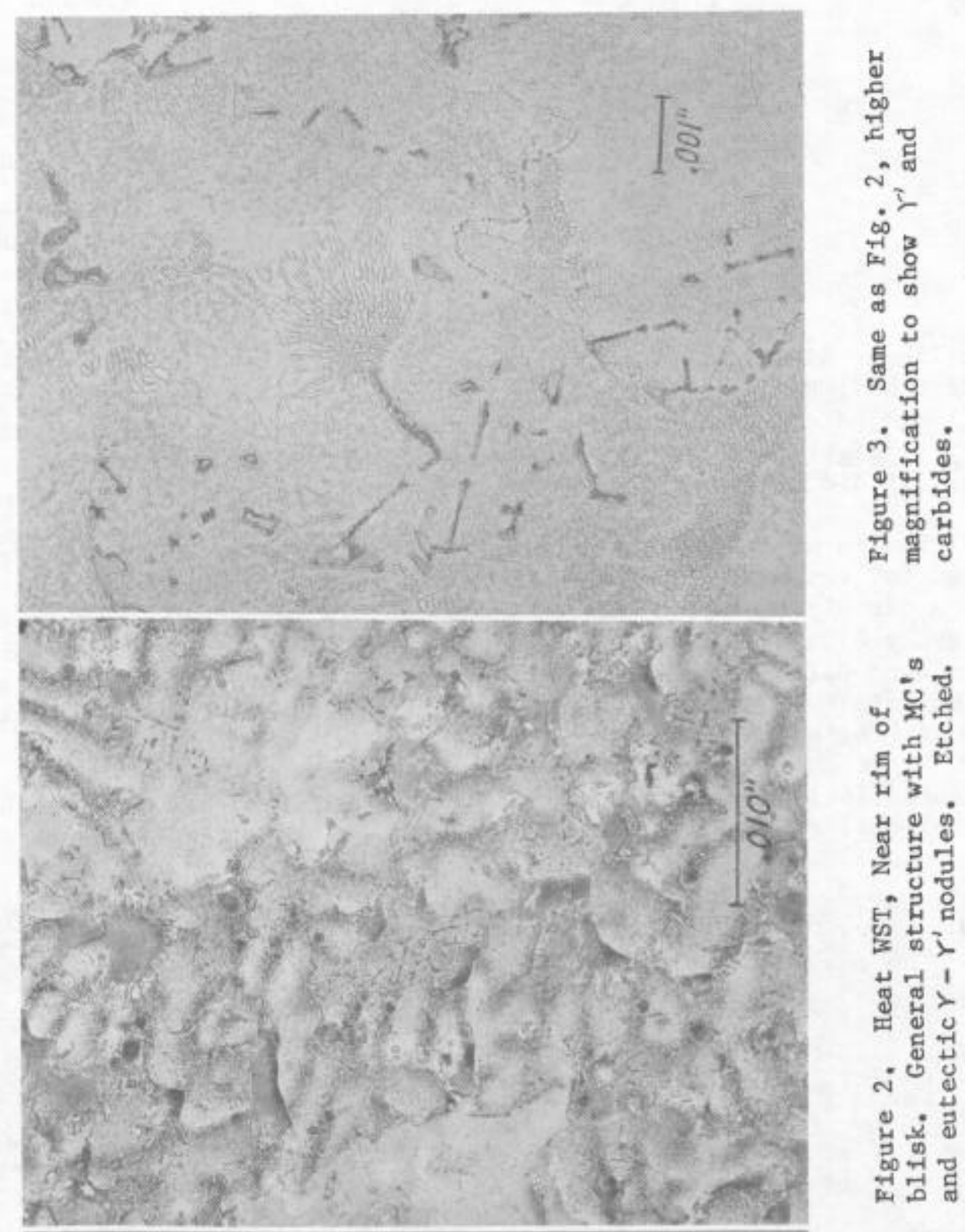

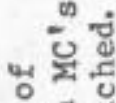

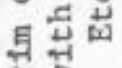

站 3

म

乙

i品品

赑出

总然京

당

$i^{\circ}$

넝

$\exists$ क

स्ते 대

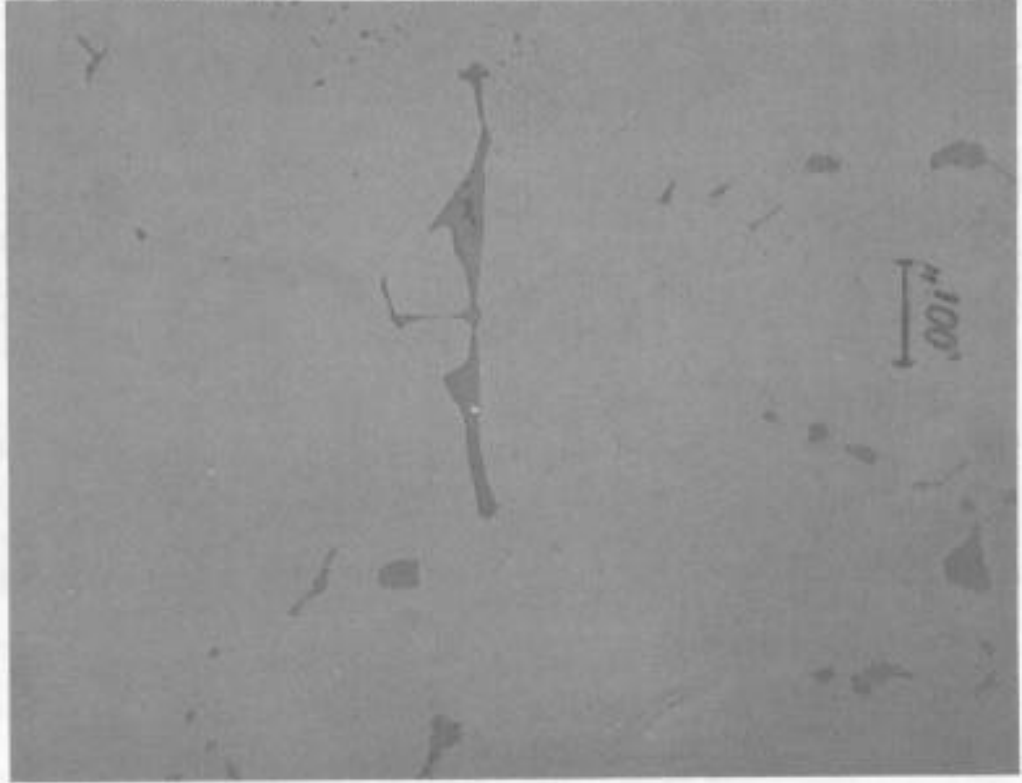

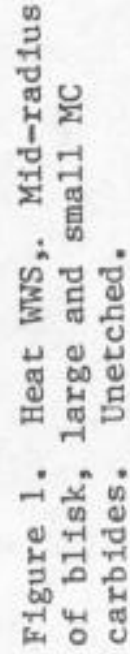


Heat No. Inspected Area $\mathrm{In}^{2}$

$\begin{array}{ll}\text { WLB } & 1.62 \\ \text { WLK } & 1.68 \\ \text { WST } & 6.17 \\ \text { WWS } & 2.93\end{array}$

Total Area

$$
\overline{12.5} \mathrm{in}^{2}
$$

Defects Found

1 dirt stringer $3 \mathrm{mils}$ long

1 "hole" $4 \times 10$ mils

2 dirt stringers: $3^{\frac{1}{2}} \mathrm{mils} ; 11 \mathrm{mils}$ long

$2 \mathrm{dirt} /$ dross: $2 \frac{1}{2} \times 6 \frac{1}{2} \mathrm{mils} ; 4 \mathrm{mfls}$ dia

1 pore or carbide pullout $1_{1 / 2}^{1 / 2} 1_{11}$ dia

2 dirt/dross: $1 \times 3 \frac{1}{2}$ mils; $2 \frac{1}{2} \times 5$ mils

The longest linear dimension of a defect was $11 \mathrm{mils}$ for a dirt (oxide?) stringer, Heat WST, Fig. 4. The largest dirt clump was in Heat WWS, Fig. 5. The $10 \mathrm{mil}$ long "hole" was found near the fracture area of a crack growth specimen. This might have been a carbide or dirt area that was opened up by the testing. It did not resemble any kind of normal porosity.

In addition to metallographic examination for defects, one blisk (Heat WWS) was used for the ECM type of successive polishing to detect non-metallic particles, A circular area $\left(4.5 \mathrm{in}^{2}\right)$ in the hub was inspected. ECM "slices" were taken every 0.020 inch for 92 planes, a total of $414 \mathrm{in}^{2}$. One $5 \mathrm{mil}$ inclusion was found 0.160 inch below the top surface (the poorer surface) and one $8 \mathrm{mil}$ inclusion was found deeper: no others above the limit of detectability (about $2 \mathrm{mils}$ ) were found.

The fractographic examination of the LCF and HCF test bars can be summarized as follows. In general, as temperatures increased and stresses and

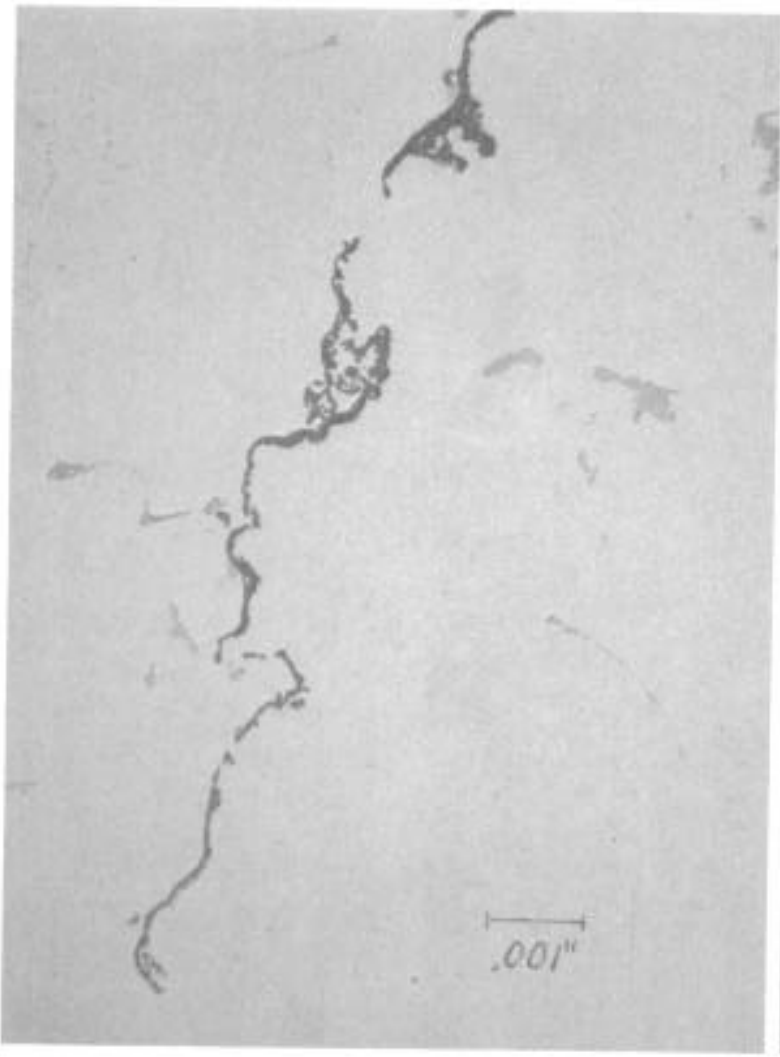

Figure 4. Heat WST. Longest linear inclusion found. Unetched

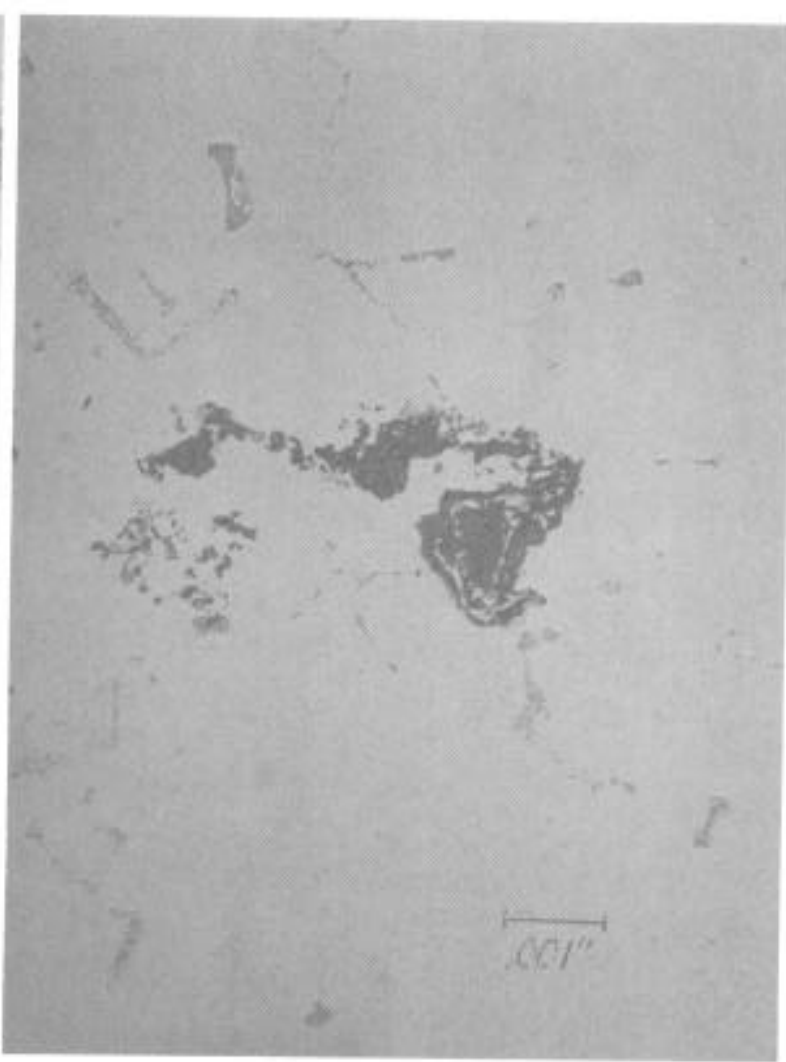

Figure 5. Heat WWS. Largest blocky inclusion found. Unetched 
A ratio decreased, there was a tendency for the fracture origin to move from the surface to the interior. No true foreign material defects ( $r$ ich in $A 1$, $\mathrm{Si}$, etc.) were found. In some cases, there were $\mathrm{Hf}, \mathrm{Ta}, \mathrm{TI}$ rich spots at the origin. These are most $11 \mathrm{kely}$ MC carbides, which is not unexpected since they are so prevalent in the structure. A few samples had $\mathrm{Cr}$ enriched areas, which may have indicated the presence of $\mathrm{Cr}$-containing carbides or dendrite segregation. They did not "glow" in the SEM as oxides would. The presence of facets at the origin area was common for both LCF and HCF specimens.

The fracture surfaces of the four crack growth rate specimens were also examined. No defects were found, but carbides and carbide clusters up to 3 mils were generally present at the initiation locations (MC carbides again verified by EDX analysis).

\section{$\underline{\text { Discussion }}$}

The mechanical properties of Mar-M-247 obtained in the present work are quite similar to those reported for Grainex(R) cast and HIP material(1)(2). The U.T.S. rises gradually from R.T. to about $1200 \mathrm{~F}$ before decreasing in agreement with the prior data, and the tensile ductility has the usual minimum near 1500-1600F. Tensile data showed a relatively small scatter, considering the varicty of castings and specimen locations involved. This has been attributed to the Grainex $(R)$ process, which avoids very coarse grains in the thicker sections, and to the HIP, which eliminates virtually all porosity and provides some additional homogenization. Notched/smooth U.T.S. ratios, while not as high as some lower strength cast alloys or wrought alloys, are still probably greater than 1.2 at temperatures under $1200 \mathrm{~F}$.

It should be kept in mind that the grain size of most of the test bars was about $1 / 8^{\prime \prime}$ diameter, which is larger than found in normal cast-to-size test bars (1/64-1/16"), and that comparisons with other alloys have to be made on this basis.

The creep and rupture times are as expected and are close to reported values. The rupture ductility at $1400 \mathrm{~F}$ is $10 \mathrm{w}$, but at 1600 and $1800 \mathrm{~F}$ is reasonably good.

Strain controlled LCF properties agreed well with prior data. Scatter in the LCF data is relatively low, again indicative of the effects of grain size control and HIP.

Very little axial-axial HCF data is available for comparison. Somewhat striking is the relatively low $A=\infty$ fatigue strength at $1100 \mathrm{~F}$; lower than at 1500 or $1700 F$. Many nickel-base alloys do show this type of HCF, A= havior - a peak fatigue strength at some intermediate temperature, with lower strength below and above it.

Crack growth rate data agrees very well with earlier data. At 1000F, the $K^{*}$ is $8 \mathrm{Ksi} \sqrt{\mathrm{in}}$ and at $1400 \mathrm{~F}$ is 12 . At both temperatures $\mathrm{K}_{\mathrm{IC}}$ was not reached up to $\geq 50$.

The microstructure of Mar-M-247 was similar in all sections examined, and is as expected for this type of alloy. A major item of interest in the structure is the MC carbide size and morphology, since they are extremely brittle, and undoubtedly can act as crack initlators and possibly easy crack growth paths. The small, blocky particles (only a fraction of a mfl in size) are not of great concern, but the elongated forms could affect fatigue and crack behavior. All the data reported here, however, is on material with 
ample carbides of this nature and therefore includes their effects. The fatigue origins on many specimens did have $\mathrm{Ti} / \mathrm{Ta} / \mathrm{Hf}$ rich MC particles present. The longest elongated carbides are about 8-10 mils. In considering casting defects (non-metallic inclusions) then, in effect, only those $>10 \mathrm{mils}$ are really significant.

\section{Conclusions}

1. Mechanical property data for Crainex(R) + HIP Mar-M-247 specimens cut from blisks including tensile, creep rupture, LCF, HCF, and crack growth results indicated that properties and cleanliness confirmed prior information and further indicated that engine applications for this material are feasible.

2. Inspection for defects revealed no porosity, and some non-metallic inclusions up to $11 \mathrm{mils}$ in length.

\section{$\underline{\text { References }}$}

1. "Grainex $(\mathrm{R})$ Cast Mar-M-247 Alloy," Technical Bulletin TB3000, Howmet Turbine Components Corporation

2. Harris, K. and R. E. Schiver, "Vacuum Induction Refining MM0011 Mar M-247 for High Integrity Turbine Rotating Parts," Cannon-Muskegon Corporation

3. Morrow, Hugh III, "The Effect of Molybdenum Content on the Microstructure and Mechanical Properties of Mar-M 247, a Cast Nicke1-Base Supera1loy," RP-57-72-04, Research Laboratory, Climax Molybdenum Co. of Michigan. Dec. 14, 1973

4. Natha1, M.V., R.D. Maier and L.J. Ebert, "The Influence of Cobalt on the Tensile and Stress-Rupture Properties of the Nickel-Base Superalloy MAR-M 247," Met. Trans. 13A, Oct. 1982

5. Ibid., "The Influence of Cobalt on the Microstructure of the Nicke1-Base Superalloy MAR-M247," Met. Trans. 13A, Oct. 1982 